\title{
CHANGES IN THE FLORA OF THE EASTERN AND SOUTHERN SHORE AREA OF LAKE PIASECZNO IN THE YEARS 2003-2010
}

\author{
Artur Serafin, Magdalena Pogorzelec \\ Department of General Ecology, University of Life Sciences in Lublin, Akademicka 13, 20-950 Lublin, Poland \\ e-mail: artur.serafin @up.lublin.pl; magdalena.pogorzelec@up.lublin.pl
}

Received: 01.02.2011

\begin{abstract}
Changes in the flora composition of the eastern and southern shore area of Lake Piaseczno, with predominantly agricultural and recreational land use in the lake catchment, were examined in the years 2003 and 2010. Multifaceted analysis of the flora was made with regard to its botanical, syntaxonomical, and ecological aspects, the identified species were assigned to different historical-geographical groups and range groups, as well as the flora synanthropisation, anthropophytisation and apophytisation indices were calculated and compared. Both the species number and the species floristic composition of the Lake Piaseczno shore zone changed in seven years. The fact that the value of the synanthropisation index remained at a similar level and a slight increase in the anthropophytisation index values are probably related to the decrease in tourist traffic in this area and the diminishing pressure from extensive agriculture.

The results of the flora analysis, in terms of the assignment of species to characteristic ecological groups, confirm the specific habitat conditions in the study area and, above all, significant permeability of the substrate and high soil nutrient availability.
\end{abstract}

Key words: flora synanthropisation, Lake Piaseczno shore area, anthropogenic impact

\section{INTRODUCTION}

The increasing human pressure on the environment causes changes in the flora of natural biocoenoses and habitats, occurring increasingly and on a larger and larger scale (F u d a $1 \mathrm{a}, 2009)$. The response of the flora at the level of plant communities, due to anthropopressure, involves changes in the range of existing natural communities as well as their simplified structure and species composition leading to their degeneration and the formation new species combinations, not naturally occurring anthropogenic communities (K o r n a ś, 1981). In areas of high natural and landscape qualities, mainly agriculture as well as stationary and unorganized tourism produce major changes in the natural flora. One of the effects of agricultural impact on the environment is the fragmentation of natural biocoenoses, creating the so-called environmental islands - parts of the natural ecosystem surrounded by areas with different ecological properties, often functioning as a valuable ecological refugium for many plant and animal species (P o u lin, 2004). As a result of farming, there are also semi-natural meadows, pastures, and segetal communities accompanying agricultural plants. Chemicalization of agricultural production, including fertilization, leads to eutrophication of oligotrophic habitats and surface waters as well as to the destruction of specialized communities and to the spread of common eurybiont species (F u d a li , 2009).

Intensive tourism induces major changes in the abiotic environment of a particular place. Increased water intake, the pressure of urban gutter water and air pollution all transform plant habitats. Habitat changes affect phytocoenoses causing their distortion, which contributes to the expansion of geographically alien species (F a bis zewski and Kwi atkowski, 2001).

As a result of collecting, uprooting and treading plants as well as littering and habitat eutrophication, natural populations of many plant species are destroyed or weakened and hemerophilous plants spread, and near technical infrastructure (roads, alleys, passageways) - synanthropic plants (F u d a li , 2009).

The purpose of this study was to conduct floristic investigations in the eastern and southern shore area of Lake Piaseczno in order to determine changes occurring in this area under the constant influence of farming and tourism pressure. 


\section{STUDY AREA}

Lake Piaseczno is located in the south-western part of the Łęczna-Włodawa Lakeland, which is a physiographic sub-unit of the Polesie Podlaskie macroregion (Fig. 1). In Poland`s administrative division, it is situated in the Lublin province, in Ludwin District, and it is a part of the Łęczna Lakeland Landscape Park, functioning as the ecological area "Lake Piaseczno and its surroundings".

Lake Piaseczno is classified as a very deep reservoir with a maximum depth of $38.8 \mathrm{~m}$, with a large capacity $\left(10.67\right.$ million $\left.\mathrm{m}^{3}\right)$, dimictic - in the bradymictic type, and in terms of trophy - mesotrophic.

It usually represents good water quality of class I or II, and in terms of susceptibility to degradation class I and II ("The annual report on the condition of the environment of the Lubelskie Voivodeship").

In the land use structure of this reservoir's catchment, natural forms dominate with a predominance of forests and meadows and pastures $(65 \%)$.

Arable land has a high share in land use because of low productivity of extensively used sandy, permeable soils.

There has been also an expansion in recreational areas which currently account for about $13 \%$ of the catchment area (F u r tak and Tu r c z y ń s k i , 1998).

From the north-west, the shore of Lake Piaseczno is adjacent to a degraded, transitional peat bog, now used as an investment area for recreational development (S e r a f i n, 2009).

The specificity of the climatic, biological and landscape factors has resulted in interest in this reservoir and its use for the purposes of stationary and unorganized recreation, which has largely affected the state of its environment.

The inflow of nutrients from agricultural and recreational activities started eutrophication processes and, as a result of that, Lake Piaseczno has changed into a water body with exceptionally transformed macrophyte communities (Baryła and Fijałkowski, 1995; Ci e cierska et al. 2000).

Similar changes can affect the shoreland flora which is a buffer for the inflow of nutrients from the drainage basin with specific land uses and thus divided into respective sectors: agriculture and marsh-forest (north-west), recreation (north-east), agriculture and recreation (east), forest and recreation (west).

\section{MATERIALS AND METHODS}

The field investigations were conducted in the years 2003 and 2010, in the spring and summer seasons. The object of the study was the eastern and southern shore area of Lake Piaseczno. A list of flora species was maintained for the shore zone of the lake with a width of $10 \mathrm{~m}$ and a length of about $1700 \mathrm{~m}$ (Fig. 1).

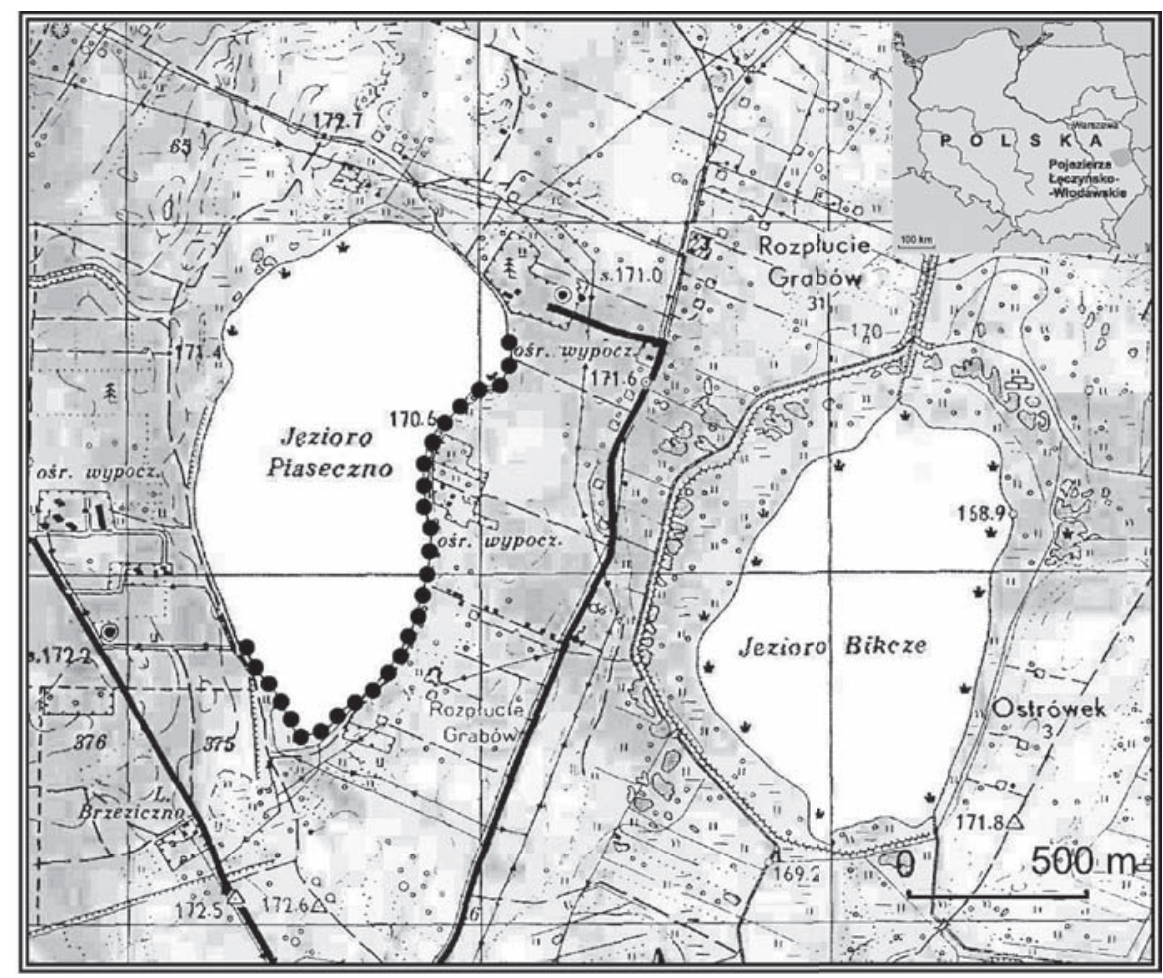

Fig. 1 Location of Lake Piaseczno - the study area and site [•].

(Part of the Topographic Map of Poland, GGK, 136.21, 1977, as amended). 
The study was conducted in stages, setting out sectors of $50 \mathrm{~m}$ in length. The observations were repeated several times, and the floristic inventories were updated three times during the season. Due to the specific structure of the location of resulting phytocoenoses and form of land use in the catchment, phytosociological investigations were not conducted and the study was focused on multilateral analysis of flora species composition in the studied area.

Due to the lack of clear differentiation in phytocoenoses along the length of the studied section of the lake shore, the floristic inventories in all the sectors were also harmonized. The species were identified using the key by R u t k ow s k i (2001), and botanical nomenclature followed M ire k et al. 2002.

In office investigations, the ecological indicator values of vascular plants ( $\mathrm{Z} \mathrm{a} \mathrm{r} \mathrm{z} \mathrm{y} \mathrm{c} \mathrm{k} \mathrm{i} \mathrm{et} \mathrm{al.} \mathrm{2002)}$ were used to determine the proportions of species belonging to different ecological groups (by using the following indices: light, moisture, acidity, trophic state, organic matter and soil texture), as well as various life-forms and syntaxonomic groups.

The species were assigned to historical-geographical and range groups (Chmiel, 1993a, 1993b), and anthropogenic changes in the flora, expressed by the following indices:

- total synanthropisation $-\mathbf{W}_{\mathrm{S}-\mathrm{c}}=\frac{A p+A}{S p+A} \times 100 \%$;

- total anthropophytisation $-\mathbf{W}_{\mathrm{An}-\mathrm{c}}=\frac{A}{S p+A} \times 100 \%$; and
- total apophytisation $-\mathbf{W}_{\mathbf{A p}-\mathbf{c}}=\frac{A p}{S p+A} \times 100 \%$; where

$A p$ - apophytes,

$S p$ - spontaneophytes + apophytes,

$A$ - anthropophytes

devised by Ch miel [1993a, 1993b], were determined and then compared, as well as the species similarity index for the flora in the years 2003 and 2010 according to Jaccard (Wys ocki and Sikorski, 2002).

\section{RESULTS}

In the studied shore zone on the east and south side of Lake Piaseczno, a total of 110 (in 2003) and 132 (in 2010) vascular plants species were identified. The constancy of occurrence related to 78 species, 32 species were recorded only in 2003, while in 2010 there were observed 54 species not previously listed in this area. The species similarity index for the flora for both years 2003 and 2010 was 0.47 .

In the years 2003 and 2010, there were representatives of 46 families in the flora of the study area. The families Asteraceae (14 species), Rosaceae (10 species), and Poaceae (10 species) were most numerously represented in 2003, while in 2010 Asteraceae (17 species), Rosaceae (17 species) and Poaceae (14 species) (Table 1).

Table 1

The species composition of the eastern and southern shore area of Lake Piaseczno, including the assignment of species to botanical classes and families in the years 2003 and 2010

\begin{tabular}{|c|c|c|c|}
\hline Class: & Magnoliopsida & \multirow{2}{*}{2003} & \multirow{2}{*}{2010} \\
\hline Families & Species & & \\
\hline Adoxaceae & Sambucus nigra & + & + \\
\hline \multirow{3}{*}{ Apiaceae } & Berula erecta & & + \\
\hline & Peucedanum palustre & + & \\
\hline & Sium latifolium & + & \\
\hline Apocynaceae & Vincetoxicum hirundinaria & + & + \\
\hline \multirow{11}{*}{ Asteraceae } & Achillea millefolium & + & + \\
\hline & Arctium lappa & & + \\
\hline & Artemisia vulgaris & + & + \\
\hline & Bellis perennis & & + \\
\hline & Bidens tripartita & + & \\
\hline & Cirsium arvense & + & + \\
\hline & Cirsium palustre & + & + \\
\hline & Conyza canadensis & & + \\
\hline & Erigeron annuus & & + \\
\hline & Eupatorium cannabinum & + & + \\
\hline & Gnaphalium uliginosum & & + \\
\hline
\end{tabular}




\begin{tabular}{|c|c|c|c|}
\hline \multirow{11}{*}{ Asteraceae } & Hieracium caespitosum & + & \\
\hline & Hieracium pilosella & + & + \\
\hline & Hieracium murorum & + & + \\
\hline & Lapsana communis & + & + \\
\hline & Leontodon hispidus & + & \\
\hline & Matricaria maritima & + & \\
\hline & Mycelis muralis & & + \\
\hline & Solidago virgaurea & & + \\
\hline & Tanacetum vulgare & + & \\
\hline & Taraxacum officinale & + & + \\
\hline & Tussilago farfara & & + \\
\hline Balsaminaceae & Impatiens parviflora & + & + \\
\hline \multirow{4}{*}{ Betulaceae } & Alnus glutinosa & + & + \\
\hline & Betula pendula & + & + \\
\hline & Betula pubescens & + & + \\
\hline & Coryllus avellana & + & + \\
\hline \multirow{3}{*}{ Boraginaceae } & Myosotis arvensis & + & + \\
\hline & Myosotis scorpioides & + & + \\
\hline & Myosotis sylvatica & & + \\
\hline \multirow{2}{*}{ Brassicaceae } & Erisimum cheiranthoides & & + \\
\hline & Capsella bursa-pastoris & + & + \\
\hline Calastraceae & Euonymus europaeus & + & \\
\hline \multirow{2}{*}{ Campanulaceae } & Campanula patula & + & + \\
\hline & Phyteuma orbiculare & + & + \\
\hline \multirow{4}{*}{ Caryophyllaceae } & Cerastium arvense & + & + \\
\hline & Dianthus superbus & & + \\
\hline & Melandrium album & + & + \\
\hline & Stellaria graminea & + & + \\
\hline Chenopodiaceae & Cheneopodium album & & + \\
\hline Convolvulaceae & Convolvulus arvensis & & + \\
\hline Dipsacaceae & Knautia arvensis & + & \\
\hline \multirow{2}{*}{ Ericaceae } & Calluna vulgaris & & + \\
\hline & Vaccinium myrtillus & & + \\
\hline \multirow{3}{*}{ Fabaceae } & Trifolium pratense & & + \\
\hline & Trifolium repens & + & + \\
\hline & Vicia tetrasperma & & + \\
\hline \multirow{2}{*}{ Fagaceae } & Quercus petraea & + & + \\
\hline & Quercus robur & & + \\
\hline Geraniaceae & Geranium palustre & & + \\
\hline Hypericaceae & Hypericum perforatum & + & + \\
\hline Juglandaceae & Juglans regia & + & + \\
\hline \multirow{8}{*}{ Lamiaceae } & Galeopsis tetrahit & + & + \\
\hline & Glechoma hederacea & + & + \\
\hline & Lamium purpureum & & + \\
\hline & Lycopus europaeus & + & + \\
\hline & Mentha aquatica & + & \\
\hline & Mentha arvensis & + & \\
\hline & Scutellaria galericulata & & + \\
\hline & Stachys palustris & + & + \\
\hline Lythraceae & Lythrum salicaria & + & \\
\hline Oleaceae & Fraxinus excelsior & + & + \\
\hline Onagraceae & Epilobium hirsutum & + & \\
\hline
\end{tabular}




\begin{tabular}{|c|c|c|c|}
\hline Papaveraceae & Chelidonium majus & + & + \\
\hline \multirow{5}{*}{ Plantaginaceae } & Linaria vulgaris & & + \\
\hline & Plantago lanceolata & + & + \\
\hline & Plantago major & & + \\
\hline & Plantago media & + & \\
\hline & Veronica chamaedrys & & + \\
\hline \multirow{4}{*}{ Polygonaceae } & Polygonum lapathifolium & + & \\
\hline & Polygonum persicaria & + & + \\
\hline & Rumex acetosella & & + \\
\hline & Rumex hydrolapathum & + & + \\
\hline \multirow{3}{*}{ Primulaceae } & Anagallis arvensis & & + \\
\hline & Lysimachia thyrsiflora & + & + \\
\hline & Lysimachia vulgaris & + & \\
\hline \multirow{3}{*}{ Ranunculaceae } & Ranunculus acris & + & \\
\hline & Ranunculus flammula & & + \\
\hline & Ranunculus repens & + & + \\
\hline Rhamnaceae & Frangula alnus & + & + \\
\hline \multirow{17}{*}{ Rosaceae } & Cerasus avium & & + \\
\hline & Comarum palustre & & + \\
\hline & Filipendula ulmaria & + & + \\
\hline & Fragaria vesca & & + \\
\hline & Geum urbanum & & + \\
\hline & Malus domestica & + & + \\
\hline & Padus avium & & + \\
\hline & Potentilla anserina & + & + \\
\hline & Potentilla collina & & + \\
\hline & Potentilla erecta & & + \\
\hline & Prunus avium & + & + \\
\hline & Prunus cerasifera & + & + \\
\hline & Pyrus communis & + & + \\
\hline & Rubus caesius & + & + \\
\hline & Rubus idaeus & + & + \\
\hline & Sorbus aucuparia & + & + \\
\hline & Spiraea media & + & + \\
\hline \multirow{3}{*}{ Rubiaceae } & Galium aparine & + & + \\
\hline & Galium mollugo & + & + \\
\hline & Galium plaustre & + & + \\
\hline \multirow{6}{*}{ Salicaceae } & Populus tremula & + & + \\
\hline & Salix alba & & + \\
\hline & Salix aurita & & + \\
\hline & Salix cinerea & + & + \\
\hline & Salix fragilis & & + \\
\hline & Salix purpurea & + & + \\
\hline Sapindaceae & Acer platanoides & + & + \\
\hline \multirow{3}{*}{ Scrophulariaceae } & Melampyrum pratense & & + \\
\hline & Rhinanthus serotinus & & + \\
\hline & Scrophularia nadosa & + & \\
\hline Solanaceae & Solanum dulcamara & + & + \\
\hline Ulmaceae & Ulmus minor & & + \\
\hline Urticaceae & Urtica dioica & + & + \\
\hline Valerianaceae & Valeriana officinalis & + & \\
\hline Violaceae & Viola tricolor & + & + \\
\hline
\end{tabular}




\begin{tabular}{|c|c|c|c|}
\hline Class: & Liliopsida & \multirow{2}{*}{2003} & \multirow{2}{*}{2010} \\
\hline Families & Species & & \\
\hline Alismataceae & Alisma plantago-aquatica & + & \\
\hline \multirow{2}{*}{ Asparagaceae } & Maianthemum bifolium & + & + \\
\hline & Convallaria majalis & + & + \\
\hline \multirow{10}{*}{ Cyperaceae } & Carex acutiformis & + & + \\
\hline & Carex echinata & & + \\
\hline & Carex elata & + & + \\
\hline & Carex nigra & & + \\
\hline & Carex paniculata & + & + \\
\hline & Carex pseudocyperus & + & \\
\hline & Elocharis palustris & + & + \\
\hline & Isolepis setacea & + & \\
\hline & Schoenoplectus lacustris & + & + \\
\hline & Scirpus sylvaticus & + & \\
\hline Iridaceae & Iris pseudacorus & & + \\
\hline \multirow{4}{*}{ Juncaceae } & Juncus articulatus & + & \\
\hline & Juncus conglomeratus & + & \\
\hline & Juncus effusus & & + \\
\hline & Luzula campestris & + & + \\
\hline \multirow{19}{*}{ Poaceae } & Agropyron repens & & + \\
\hline & Agrostis capillaris & + & \\
\hline & Calamagrostis arundinacea & & + \\
\hline & Calamagrostis canescens & + & \\
\hline & Calamagrostis epigeios & & + \\
\hline & Dactylis glomerata & & + \\
\hline & Hierohloë odorata & & + \\
\hline & Holcus lanatus & + & \\
\hline & Lolium perenne & + & \\
\hline & Molinia caerulea & & + \\
\hline & Nardus stricta & & + \\
\hline & Phalaris arundinacea & + & \\
\hline & Phleum pratense & & + \\
\hline & Phragmes australis & + & + \\
\hline & Poa angustifolia & & + \\
\hline & Роа аппиа & + & + \\
\hline & Poa palustris & + & + \\
\hline & Poa pratensis & + & + \\
\hline & Poa trivialis & + & + \\
\hline Typhaceae & Typha latifolia & + & + \\
\hline Class: & Equisetopsida & \multirow{2}{*}{2003} & \multirow{2}{*}{2010} \\
\hline Families & Species & & \\
\hline \multirow{2}{*}{ Equisetaceae } & Equisetum arvense & + & + \\
\hline & Equisetum fluviatile & + & \\
\hline Class: & Polipodiopsida & \multirow{2}{*}{2003} & \multirow{2}{*}{2010} \\
\hline Families & Species & & \\
\hline Dennstaedtiaceae & Pteridium aquilinum & + & + \\
\hline Dryopteridaceae & Dryopteris filix-mas & + & \\
\hline Thelypteridaceae & Thelypteris palustris & + & + \\
\hline Class: & Coniferopsida & \multirow{2}{*}{2003} & \multirow{2}{*}{2010} \\
\hline Families & Species & & \\
\hline Pinaceae & Pinus sylvestris & + & + \\
\hline
\end{tabular}


Hemicryptophytes, whose share exceeded 50\% during the investigations in both years, were predominant in the species composition of the flora; a large proportion of geophytes and therophytes were also observed (Table 2).

In both years, among the species belonging to the specific historical-geographical groups, apophytes were the most numerous group (about $40 \%$ of species), non-synanthropic spontaneophytes were much less recorded.

Among the species that were reported in the 2010 study and did not occur in 2003, apophytes had the largest percentage. Apophytes, together with anthropophytes, accounted for more than 50\% of species recorded the first time (Table 3 ).

Table 2

The proportions of different plant life-forms in the flora of the study area in the years 2003 and 2010

\begin{tabular}{|c|c|c|c|c|}
\hline \multirow[b]{2}{*}{ Life forms (f) } & \multicolumn{2}{|c|}{2003} & \multicolumn{2}{|c|}{2010} \\
\hline & $\begin{array}{l}\text { Number of } \\
\text { species }\end{array}$ & $\begin{array}{l}\text { Proportion } \\
{[\%]}\end{array}$ & $\begin{array}{l}\text { Number of } \\
\text { species }\end{array}$ & $\begin{array}{l}\text { Proportion } \\
{[\%]}\end{array}$ \\
\hline $\begin{array}{l}\mathbf{M} \text { - megaphanerophytes, trees generally growing to } \\
\text { a height of over } 5 \mathrm{~m}\end{array}$ & 10 & 9.09 & 16 & 12.12 \\
\hline $\begin{array}{l}\mathbf{N} \text { - nanophanerophytes, shrubs and small trees, } \\
\text { from } 0.5 \text { up to } 5 \mathrm{~m} \text { in height }\end{array}$ & 12 & 10.9 & 12 & 9.09 \\
\hline Ch - woody chamaephytes (buds $>25 \mathrm{~cm}$ above ground) & 0 & 0 & 1 & 0.75 \\
\hline C - herbaceous chamaephytes (buds $<25 \mathrm{~cm}$ above ground) & 2 & 1.81 & 5 & 3.78 \\
\hline $\mathbf{H}$ - hemicryptophytes (buds at ground level) & 64 & 58.18 & 69 & 52.27 \\
\hline G - geophytes (buds in soil) & 16 & 14.54 & 21 & 15.9 \\
\hline $\mathbf{T}-$ therophytes (annuals) & 14 & 12.72 & 21 & 15.9 \\
\hline Hy - hydrophytes and helophytes (buds in water) & 15 & 13.63 & 11 & 8.33 \\
\hline li - lianas (plants rooted in soil, requiring supports) & 1 & 0.9 & 2 & 1.51 \\
\hline pp - semi-parasites & 0 & 0 & 2 & 1.51 \\
\hline - species of undetermined affinity & 3 & 2.72 & 3 & 2.27 \\
\hline Total & 137 & 124.49 & 163 & 123.43 \\
\hline The number of species actually occurring in the study area & 110 & 100 & 132 & 100 \\
\hline
\end{tabular}

Table 3

The proportions of historical-geographical groups in the flora of the study area in the years 2003 and 2010

\begin{tabular}{|c|c|c|c|c|c|c|}
\hline \multirow{2}{*}{\multicolumn{3}{|c|}{ Historical-geographical group }} & \multicolumn{2}{|c|}{2003} & \multicolumn{2}{|c|}{2010} \\
\hline & & & \multirow{2}{*}{$\begin{array}{c}\begin{array}{c}\text { Number of } \\
\text { species }\end{array} \\
44\end{array}$} & \multirow{2}{*}{$\begin{array}{c}\begin{array}{c}\text { Proportion } \\
{[\%]}\end{array} \\
40.0\end{array}$} & \multirow{2}{*}{$\begin{array}{c}\begin{array}{c}\text { Number of } \\
\text { species }\end{array} \\
50\end{array}$} & \multirow{2}{*}{$\begin{array}{c}\begin{array}{c}\text { Proportion } \\
{[\%]}\end{array} \\
37,9\end{array}$} \\
\hline & & $\begin{array}{c}\mathrm{Sp}-\text { non-synanthropic } \\
\text { spontaneophytes }\end{array}$ & & & & \\
\hline & & Ap - apophytes & 52 & 47.3 & 57 & 43,2 \\
\hline \multirow{3}{*}{ Antropophytes } & 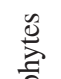 & Arch - archeophytes & 2 & 1.8 & 5 & 3,8 \\
\hline & 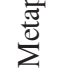 & Ken - kenophytes & 2 & 1.8 & 4 & 3,0 \\
\hline & & D - diaphytes & 0 & 0.0 & 0 & 0,0 \\
\hline \multicolumn{3}{|c|}{ - species of undetermined affinity } & 10 & 9.1 & 16 & 12.1 \\
\hline \multicolumn{3}{|l|}{ Total } & 110 & 100 & 132 & 100 \\
\hline
\end{tabular}

Spontaneophytes were a large group (43\%) among the plants who disappeared from the species composition between 2003 and 2010, and the number of anthropophytes increased from 4 species recorded in 2003 to 9 in the year 2010. In 2010 species such as Vicia tetrasperma, Lamium purpureum, Anagallis arvensis (archeophytes), Conyza canadensis and Erigeron аппии (kenophytes) as well as a garden variety Dianthus superbus appeared in the company of species such as Myosotis arvensis, Capsella bursa-pastoris (ar- 
cheophytes) as well as Impatiens parviflora and Prunus avium (kenophytes) present at the study site in 2003,.

The flora synanthropisation index (determining the percentage proportion of antropophytes and apophytes) decreased in value from $52.7 \%$ in 2003 to $50 \%$ in 2010. The flora apophytisation index (determining the share of apophytes in the flora) also declined from $47.3 \%$ to $43.2 \%$, while the flora antropophytisation index (determining the percentage of antropophytes) increased significantly from $3.6 \%$ to $6.8 \%$.

In the flora of the studied area, 7 (in 2003) and 6 (in 2010) geographical (range) elements, in the strict meaning, were identified. Euro-Siberian, Middle-Siberian and cosmopolitan species had the largest proportion. Circumboreal species had a lower share and the remaining species were overlapping elements that go beyond the basic phytogeographical units (Table 4).

The analysis of the geographical range of antropophytes showed that they were most strongly associated with Euro-Siberian boreal flora $(33 \%$ and $36 \%$ of antropophytes) and the Central-European geographical group ( $21 \%$ and $23 \%$ of antropophytes). Cosmopolitan species also made up a significant proportion of the group of antropophytes (19\%).

Table 4

The proportions of geographical (range) elements in the flora of the study area in the years 2003 and 2010

(CB - circumboreal; ES - Euro-Siberian; E - Central European; sOZ - sub-Atlantic; P - Pontian-Pannonian;

ZAS - Central Asiatic; M - Mediterranean; IT - Irano-Turanian; AM - American; KOSM - cosmopolitan)

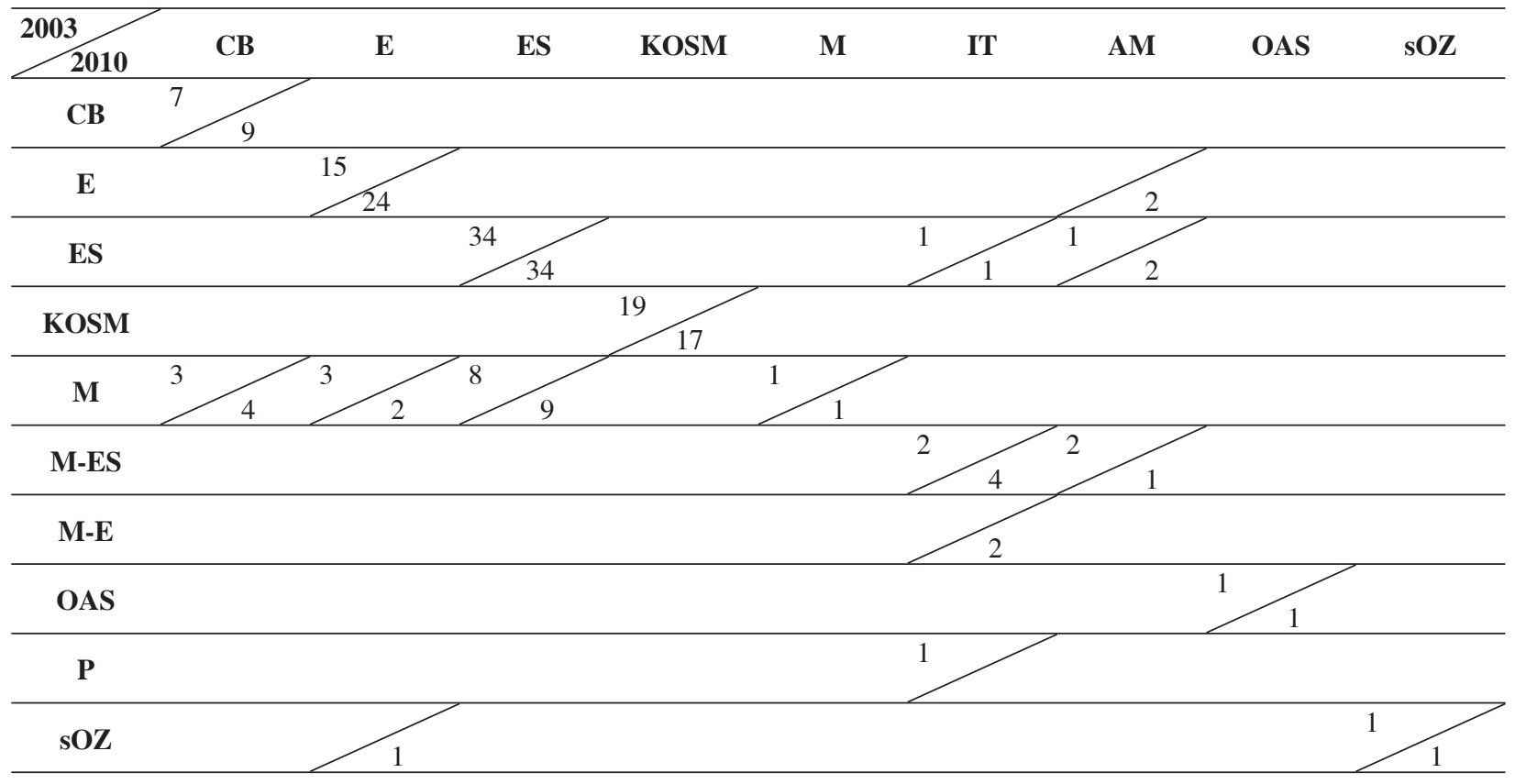

Table 5

The percentage proportions of plant species with different habitat requirements in the flora of the study area in the years 2003 and 2010 (calculated using the ecological indicator values, Zarzycki et al. 2002)

\begin{tabular}{|c|c|c|c|c|c|c|c|c|}
\hline \multirow{2}{*}{ Selected indicators } & \multirow{2}{*}{ Years } & \multicolumn{6}{|c|}{ Ecological indicator values } & \multirow{2}{*}{ Stenobionts } \\
\hline & & 1 & 2 & 3 & 4 & 5 & 6 & \\
\hline \multirow{2}{*}{$\mathrm{L}$ - light value } & 2003 & 0.00 & 6.36 & 23.63 & 65.45 & 28.18 & 0.00 & 74.54 \\
\hline & 2010 & 0.00 & 6.81 & 22.72 & 67.42 & 28.78 & 0.00 & 73.48 \\
\hline \multirow[b]{2}{*}{$\mathrm{W}$ - soil moisture value } & 2003 & 0.00 & 16.36 & 56.36 & 40.90 & 20.00 & 5.45 & 30.90 \\
\hline & 2010 & 0.00 & 18.93 & 62.12 & 40.90 & 25.00 & 4.54 & 48.48 \\
\hline \multirow{2}{*}{$\mathrm{Tr}$ - trophy value } & 2003 & 0.90 & 7.27 & 52.72 & 73.63 & 5.45 & 0.00 & 54.54 \\
\hline & 2010 & 0.75 & 14.39 & 55.30 & 63.63 & 7.57 & 0.00 & 53.03 \\
\hline \multirow{2}{*}{$\mathrm{R}$ - soil (water) acidity $(\mathrm{pH})$ value } & 2003 & 0.90 & 2.72 & 26.36 & 81.81 & 40.00 & 0.00 & 50.90 \\
\hline & 2010 & 2.27 & 10.60 & 35.60 & 75.75 & 34.09 & 0.00 & 46.21 \\
\hline \multirow{2}{*}{ D - soil granulometric value } & 2003 & 1.81 & 10.90 & 38.18 & 83.63 & 38.18 & 0.00 & 35.45 \\
\hline & 2010 & 2.27 & 15.15 & 39.39 & 84.09 & 34.09 & 0.00 & 35.60 \\
\hline \multirow{2}{*}{$\mathrm{H}-$ organic matter content value } & 2003 & 6.36 & 72.72 & 31.81 & 0.00 & 0.00 & 0.00 & 81.81 \\
\hline & 2010 & 10.6 & 79.54 & 29.54 & 0.00 & 0.00 & 0.00 & 76.51 \\
\hline
\end{tabular}


The specific structure (qualitative and quantitative) of species in the phytocoenoses found in the research area did not allow us to carry out an accurate classification of syntaxa. However, in the flora there was noted a large share of species characteristic for the classes Alnetea glutinosa (20 and 20 species, alder and willow thickets) and Stellarietea mediae (13 and 15 species; this class includes anthropogenic nitrophilous field communities and ruderal annual plants), and for the alliance Alno-Ulmion (alluvial forests, 14 and 17 species).

The results of the analysis based on the indicator values ( $\mathrm{Zarzycki}$ et al. 2002), describing the preferences of species, allowed us to find that hydrophilous plants, characteristic of both fresh soils and moist wet soils, were the main component of the flora. The plant species that colonized the shore zone of Lake Piaseczno - by their specific preferences - indicated nutrient rich soils (eutrophic) and moderately nutrient poor soils (mesotrophic), although the narrow range of ecological tolerance in relation to this factor characterized more than half of the species. The largest group of species indicated neutral soils with a $\mathrm{pH}$ of 6.0-7.0. According to the study of the organic matter content level and the soil granulometric composition, there was found a predominance of species preferring sandy clays and silty deposits as well as mineral-humic soils (at the same time, with a large proportion of species having a narrow range of ecological tolerance; (Table 4).

\section{DISCUSSION AND CONCLUSIONS}

The environmental transformations in the Łęczna-Włodawa Lakeland are the results of many anthropogenic pressures, among which the changes in hydrology resulting from land drainage, the influence of the Wieprz-Krzna Canal system, and the consequences of coal mining are the most important (S e r a f i n , 2009).

At the local level, the status of catchment management associated with the intensity of agriculture and tourism affects fundamentally the state of lake ecosystems. In the case of Lake Piaseczno, the poor quality of permeable sandy podzolic soils, which is not conducive to agricultural intensification, plays the important role in groundwater nutrient enrichment ( $\mathrm{M} \mathrm{i} \mathrm{s} \mathrm{z} \mathrm{tal}$ and S m a 1, 1995). Similarly, the change in Lake Piaseczno catchment management in the direction of tourism and recreation, at the expense of arable land, did not affect the decrease in the inflow of nutrients, but only changed their origin (S e r a fi n and C zer n a ś, 2003).

This is confirmed by the analysis of the ecological indicator values for vascular plants in the studied sections of the shore area in the years 2003 and 2010, at the same time evidencing the typology of soils and the eutrophication of habitats once described as oligotrophic (Fij ałk ow ski, 1959).

The impact of agriculture and tourism on the natural environment of Lake Piaseczno is also confirmed by the presence of fragmented areas in the eastern and southern shore area which look like natural biocoenoses with a mosaic of arable land and uncultivated land used for recreation (beaches).

Changes in habitat conditions must therefore also affect anthropogenic changes in the ecosystems evidenced by transformations in the plant communities, including the synanthropisation, anthropophytisation and apophytisation processes of the flora.

One of the major risks which are inherent to progressive flora synanthropisation is the loss the original natural communities and species combinations. The encroachment of alien species is still observed, but their appearance only apparently increases species diversity in the habitats. The flora of the area is enriched only at the beginning of the process; the next step is usually the withdrawal of the native taxa under the pressure of competition from better adapted species (Kornaś, 1977).

Both the number of species and species composition of the flora of the Lake Piaseczno shore zone changed in seven years. The analysis of the collected information indicates a relatively fast exchange of components of the flora in the study area. The results of the present research show a significant share of native species characteristic for our geographical zone, but the appearance of taxa associated with anthropopressure and, above all, the increasing value of the flora anthropophytisation index may arouse concern.

According to Korn as (1977), the number of apophytes found in a given area grows constantly with the increasing number of years of observation, as the number of observations of incidental components increases. The best indicator of flora synanthropisation must be the total number of all alien components recorded within the flora.

Comparing the results of the present study with the information given by other authors from other areas with varying degrees of anthropopressure (K $1 \mathrm{imk} \mathrm{o}$ and B o zi o, 2003; Kry s zak, 2004; G a m r a t and K o c h a n ow s k a , 2009), the flora synanthropisation index for the study area was not high. This is probably associated with a decrease in tourist traffic in this area and diminishing pressure from extensive agriculture.

\section{REFERENCES}

Baryła R., Fijałkowski D. 1995. Roślinność naczyniowa jezior i torfowisk w rejonie Poleskiego Parku Narodowego i jego otuliny. [In]: Ochrona ekosystemów wodnych w Poleskim Parku Narodowym i jego otulinie. S. Radwan (ed.), TWWP, AR Lublin, 79-84. (in Polish) 
Chmiel J. 1993 a. Flora roślin naczyniowych wschodniej części Pojezierza Gnieźnieńskiego i jej antropogeniczne przeobrażenia w wieku XIX i XX. Część I. Sorus, Poznań: 56-58, 97-98. (in Polish)

Chmiel J. 1993 b. Flora roślin naczyniowych wschodniej części Pojezierza Gnieźnieńskiego i jej antropogeniczne przeobrażenia w wieku XIX i XX. Część II. Atlas rozmieszczenia roślin. Sorus, Poznań. (in Polish)

Ciecierska H., Sender J., Biedunkiewicz A. 2000. Struktura roślinności wodnej i szuwarowej jeziora Piaseczno na Pojezierzu Łęczyńsko-Włodawskim. [In]: Problemy ochrony i użytkowania obszarów wiejskich o dużych walorach przyrodniczych. (eds) S. Radwan, Z. Lorkiewicz, Wyd. UMCS, Lublin. (in Polish)

Fabiszewski J., Kwiatkowski P. 2001. Gatunki inwazyjne we florze roślin naczyniowych Sudetów. Ann. Siles., 31: 123-128. (in Polish)

Fijałkowski D. 1959. Szata roślinna jezior łęczyńsko-włodawskich i przylegających do nich torfowisk. Ann. UMCS, sect. B, XIV, 3: 131-207. (in Polish)

Fudali E. 2009. Antropogeniczne zmiany w ekosystemach. Transformacje roślinności. Wyd. UP we Wrocławiu, Wrocław. (in Polish)

Furtak T., Turczyński M. 1998. Zmiany w zagospodarowaniu zlewni jezior na przykładzie Piaseczna. [In]: Jeziora Łęczyńsko-Włodawskie. Monografia przyrodnicza. (eds) M. Harasimiuk, Z. Michalczyk, M. Turczyński UMCS, PIOŚ, Bibl. Monit. Środ., Lublin. (in Polish)

Gamrat R., Kochanowska R. 2009. Zróżnicowanie zbiorowisk łąkowych w dolnej części doliny Iny na tle warunków siedliskowych. / Variation in meadow communities in the lower part of the Ina valley relative to habitat conditions. Folia Pomer. Univ. Technol. Stetin. 2009, Agric., Aliment., Pisc., Zootech. 274 (12), 5-10. (in Polish)

Klimko M., B ozio A. 2003. Flora synantropijna Nowego Tomyśla. Roczniki Akademii Rolniczej w Poznaniu, CCCLIV: 73-91. (in Polish)

Kornaś J. 1981. Oddziaływanie człowieka na florę: mechanizmy i konsekwencje. / Human effects on flora: mechanisms and consequences. Wiadomości Botaniczne XXV (3): 165-182. (in Polish)

Kornaś J. 1977. Analiza flor synantropijnych. / Analysis of synanthropic floras. Wiadomości Botaniczne. XXI (2) 85-91. (in Polish)

Kryszak A. 2004. Synantropizacja wybranych zbiorowisk łąkowych. / Synanthropization of some meadow communities. Woda - Środowisko - Obszary wiejskie 4, 1 (10): 201-208. (in Polish)

Mirek Z., Piękoś-Mirkowa H., Zając A., Zając M. 2002. Flowering plants and pteridophytes of Poland. A checklist. W. Szafer Institute of Botany, Polish Academy of Sience, Kraków.

Misztal M, Smal H. 1995. Gleby Poleskiego Parku Narodowego i w jego otulinie. [In]: Ochrona ekosystemów wodnych w Poleskim Parku Narodowym i jego otulinie. S. Radwan (ed.). TWWP, AR Lublin, 70-78. (in Polish)
Poulin A.S. 2004. Biologiczne podstawy ochrony przyrody. Państwowe Wydawnictwo Naukowe, Warszawa. (in Polish)

Rutkowski L. 2001. Klucz do oznaczania roślin naczyniowych Polski niżowej. Państwowe Wydawnictwo Naukowe, Warszawa. (in Polish)

Serafin A. 2009. Phytoplankton productivity in the pelagic zone of Piaseczno Lake in the evaluation of its trophic state in the summer seasons of 2005-2007. Teka Kom. Ochr. Kszt. Środ. Przyr. - OL PAN, 2009, 6: 304-310.

Serafin A., Czernaś K. 2003. Sezonowe zmiany produkcji pierwotnej i koncentracji chlorofilu a glonów śródjezierza i strefy przybrzeżnej mezotroficznego jeziora Piaseczno w latach 2001-2002. / Seasonal changes in primary production and chlorophyll $a$ concentration for algae in the inlake and shore zone of the mesotrophic Lake Piaseczno in 2001-2002. Acta Agroph. 1(3), 521527. (in Polish)

Wys ocki C., Sikorski P. 2002. Fitosocjologia stosowana. Wydawnictwo SGGW, Warszawa. (in Polish)

Zarzycki K., Trzcińska-Tacik H., Różański W., Szeląg Z., Wołek J., Korzeniak U. 2002. Ecological indicato values of vascular plants of Poland. Ekologiczne liczby wskaźnikowe roślin naczyniowych Polski. W. Szafer Institute of Botany, Polish Academy of Science, Kraków.

\section{Zmiany we florze wschodniej i południowej części pobrzeża jeziora Piaseczno w latach 2003-2010}

\section{Streszczenie}

W latach 2003 i 2010 badano zmiany składu gatunkowego flory wschodniej i południowej części pobrzeża jeziora Piaseczno, z przewagą rolniczo-rekreacyjnego zagospodarowania zlewni. Dokonano wielopłaszczyznowej analizy flory pod względem botanicznym, syntaksonomicznym, ekologicznym, określono przynależność gatunków do grup historyczno-geograficznych i zasięgowych, oraz obliczono i porównano wskaźniki synantropizacji, apofityzacji i antropofityzacji flory. Zarówno liczba gatunków, jak i skład gatunkowy flory strefy przybrzeżnej jeziora Piaseczno uległy zmianom w okresie siedmiu lat. Utrzymywanie się wartości wskaźnika synantropizacji na podobnym poziomie i niewielki wzrost wartości wskaźnika antropofityzacji związane są prawdopodobnie ze zmniejszeniem natężenia ruchu turystycznego na tym terenie i coraz mniejszą presją ekstensywnego rolnictwa. Wyniki analizy flory pod względem przynależności gatunków do charakterystycznych grup ekologicznych potwierdzają specyficzne warunki siedliskowe panujące w terenie badań, a przede wszystkim znaczną przepuszczalność podłoża i zasobność gleb w składniki pokarmowe. 